\title{
The Permanent Settlement of Bengal
}

TT is now just a century ago that the permanent settlement of the 1 land revenue of Bengal was completed. Finsncially this settlement involved the bold step (it would have been thought madness in any other department of the revenue) of stereotyping for all time the figares of the land revenue account which is the chief item of state income; it was carried out in apparent unconsciousness alike of the probable emberrassment of foture governments, and of the incalculsble changes in the value of money as well as of land and its produce that time was bound to bring about. Socially it gave rise to what was virtually a new class of (legal) landlords; and, albeit indirectly, it revolutionised the land tenures generally, by crystallising into legal rigidity relations which were gradually developing themselves with oriental lamess onder the varying impuise of local circumstances.

Such a settlement has naturally left a heavy legacy of legal and administrative trouble not yet wholly disposed of. The history of the settlement is, therefore, something more than a mere mstter of coriosity ; it contains not a few lessons for modern times, and furnishes some parallels with agrarian troubles nearer home. Many acconts of it have been written, but the facts have not always been stated fairly; rarious and sometimes inaccurate presentations have been made, in the eagerness of adrocates of this or that policy to establish their case.

In order to derive practical benefit from the history, there is still room to welcome additional information, especially when that addition comes in the shape of a more direct means of verifying conclusions and establishing disputed points. The four handy volumes which Sir William Hunter has recently issued ' contain a classified abstract of the more inportant official letters received by and issued from the chief revenue office in Calcutta during the first twenty-five jears of its existence. This marks a new departure; for the records throw a direct and original light on the working of the administration under Lord Cornwallis's system, a light different from that

1 Bengal MSS. Rocords : a Selected List of 14,136 Lettors in the Board of Revenene, Calcutta (1782-1807), by Sir W. W. Bunter, K.C.S.I. \& volg. London: Allen \& Co. 1894. 
given by the bare text of regulations, minates, and parliamentary reports. The letters furnish us with concrete instances-with so many ' leading cases' showing the specific application and the real intention and effect of the rales. The abstracts will, it is true, find their follest ase in India, where further reference can be made to the entire document; but in general Sir W. Hunter's abstracts are so good, in spite of their necessary brevity, that they contain in themselves the essential information required. Naturally, in order to make good use of such material, the reader must have a certain familiarity with the facts and the law of the settlement, but this is now easily attainable. Moreover, in view of such a need, the list of letters is preceded (in vol. $i$ ) by an illustrative dissertation on the settlement proceedings which in itself would entitle the work to take high rank among our authorities on the administrative history of Bengal.

The land revenue administration is so important that every large Indian province has found it indispensable to have a special department for its chief control. In Bengal, practically since 1782, there has been 8 'board of revenue,' with whatever rariety of offcial title or difference of internal constitution. Before this board every serious question of land revenue policy ultimately comes.

The period from 1782 to 1812 forms a distinct epoch in the history of the administration. It begins with the sear in which it may fairly be said that the machinery of revenue control, local and central, had acquired its modern form, and had begun to work on defined lines of regulated procedure. ${ }^{2}$ The capabilities of this machinery were first serionsly tested in the making of the decennial settlement, which was declared permanent; and the details of this settlement, and the questions that arose out of it, naturally form the most important topic of the correspondence daring the earlier years of the period. The latter part includes the years during which the difficulties created by the settlement began to be acutely felt, especislly in connerion with the law of tenancy and rent recovery. Sir W. Hanter's volumes do not embrace the entire epoch; they end with 1807-taking the round term of a quartar of a century.

Never, perhaps, was an administrative experiment tried with such excellent intentions as the Bengal settlement, never was one which had results so different from those expected. In truth, the experiment was made under almost every possible disadvantage. If Bengal had been a well-managed native province, we might have

\footnotetext{
2 Prom 1765 (tho date of the grant of Bengal, Bihar, and Orisea) to 1771, the attempt was mado to maintain the old native official gystam inteot, bat sabject to a certain supervision. The years 1772-1781 maj be rogarded as s second stage, during which the essenticl foatores of modern organisation-the 'dirtrict, with its collector and his assigtente, the revenue 'division,' with its 'commierioner' (to supervise a group of digtricta), and the board of revenue (in direct commnniention with the provineial government)-were gradnally, and with many retroppessions, nrolved.
} 
succeeded to a revenue system which would not indeed have conformed to English notions of precision or legality, but would heve been practically workable in a paternally despotic fashion, and might have been gradually adapted to western requirements. As it was, the province came to us in the last stage of administrative decay. It had never been more than an outlying and imperfectly connected member of the Moghal empire, and not only soonest fell a prey to the disease that was infecting the whole system, bat had never shared the foller circulation of vitality which maintained prosperity in the provinces nearer the heart of the empire. Though nominally added to the dominions of the early Pathan emperors of Delhi, Bengal had become an independent kingdom in the fourteenth century ; and it maintsined its position largely by the countensnce given to the old Hindu princes and chiefs who raled a series of states, which. according to the usual Hindu model, were-regarded as kingdoms-always of small size. They were left in practical independence on condition of accepting a sanad or grant implying political subjection, and of passing on to the treasury of the Mushim king a considerable share of the land revenue locally collected.

The genius of Akbar enabled him once more to anner Bengal and make it a suba or province of the Moghal empire. Sir W. Hanter is perhaps inclined somewhet to andervalue the extent to which Akbar's revenue settlement (eirca 1582 A.D.) affected the province. It is true that the districts were not actually measuredthat process was only carried out in Bihar-but a fair list was made out of the parganas or local fiscal subdivisions and of their assessments based on the rental of the village groups in each. ${ }^{3}$ And there were subsequent formal settlements between 1658 and 1728.

The system of farming the revenues became general daring the latter part of the reign of Aurangzib ; and in the last settlement (1728) we find the system folly established, as the acconts proceed solely according to the series of ihtimam or farmerg' charges which had virtaally superseded the official fiscal divisions established in the days of direct control. After this settlement, we only know of the continually increasing levy of ' cesses ' (abrcab), imposed, on all sorts of pretences, in addition to the nominal land revenue. In the end we find a kind of annual settlement (or rather bargain) made with the farmers; and this had continued for some time before British rule began."

I The seond ralume of the Ayim-i-Akbari shows this alearly. Jobn Share (minnto of Juno 1789, per. 11, Bifh Report, vol. i. p. 108, Medrae reprint) wroto that the settloment comprebended not only the quota (total ronta) payable by the villegea, bath ' as is genenally believed, by the individual ryota' This asesument conld hardly have beon soospted and sppealed to 20 it was, if it hed bean summery or incomplote.

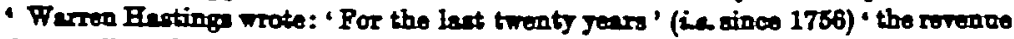
hes been collected on a conjectoral valuation' with reforence to pact colloctions and the opinion of offloials ; and 'it res sitered stmost overy jear.' 
No wonder then that for some years the British anthoritieg feared to touch the tottering edifice of native management lest it should crumble to pieces under their hands, and contented themselves with trying to prop it up and remedy its worst abuses. When at last, in 1772, direct administration was forced upon the Governor-general, he had to begin the heavy task with a staff of officers uamerically insufficient and, as a rule, without experience of land management. As if to add to our difficulties, a terrible famine had recently desolated the province; and what its effects were may be jadged from the touching description in the 'Annals of Raral Bengal,' a book which was the first of that raluable series in which Sir W. Houter has, with rare success, made the dry facts of Indian history to live and move, as it were, before our eyes.

The land revenue of Bengal had long been levied in money. This, however, was, comparatively speaking, an innovation. In a simple stage of society, it is convenient to levy the contribution in its original form, viz. by taking a share of the actual grain produce of each holding as it lay on the threshing floor. When this is done, no question arises about the tenure of the cultivator or the value of his land. The share belonging to the king is fired by immemorial custom. But, in the course of time, circumstances both economic and political (which cannot bere be discussed) are gradually found to necessitate the substitution of cash rates for each holding or for a certain unit area of land; and then it is that the more modern difficulties of revenue management begin. Attention is, in fact, diverted from the land, the produce of which is to be divided, to the person, who is to be responsible for the cash payment; and it is soon found (as the revenue-psyer is not always the immediate holder or cultivator of the land) that the administration cannot long ignore the relations of that person to the soil cultivators as well as to the state.

All native governments adopted one or other of two methods. (1) They dealt direct with each separate village, sometimes collecting the individual payments of the cultivators, sometimes holding a headman, or other person, responsible for the village total.s Under this system-which marks the best days of native rulethere is a regular graduated control, from the accountant in each village, to the kanuingo in each small subdivision, and from him to the district officer, and finslly to the sadr-kaningo, or financial controller, who advised the diran, or chief civil offeer of the

- In some parts of India, where the villages ware held in shares by a joint body, the rillege revenne wes in one sum, for which the body was jointly responsible, distributing the burden, aceording to their own exstorn. This wes not the case in Bengal propor. The barbarous Bengel custom aalled nüjaii, whereby the farmen mede the solvent coltivators pay the arrears of a defenlter, was a pare act of tyranoy and was soon abolished ander Britiah role. 
whole province. (2) A larger 'estate' was taken, the particulars of the component revenue divisions, villages, \&c., being stated in a sanad or warrant of appointment, and a farmer was made responsible for the total sum, subject to certain specified allorrances for charges and remuneration. Such an 'estate' might be only a single pargana, or might cover an extensive district. Under this system the local revenue control above spoken of, soon becomes atrophied and useless.

In Bengal the first of these methods had originally been adopted, at least over a considerable part of the country; bat (as already stated) since the reign of Aurangzīb it had given way more and more completely to the second. The cause of the change was partly the weakness of the local government, and partly the fact that the surviving Hindu rajjas had all along been allowed to administer (and farm the revenues of) their former territories. Wherever there was no räja, or other local chief of sufficient importance, official farmers and.speculators were appointed to manage the revenue. All that was really looked to was that the total sum specified in the warrant should be paid into the treasury.

In process of time all 'zamindars,' as these revenue farmerg were officially called, beckme fused into one class, and their varions origin was more or less forgotten. One of the most valuable parts of Sir W. Hunter's dissertation (vol.. i. pp. 31 ff.) is that which places before the reader the different elements thus fused together. The fact that some of the 'zamindars' had old territorial claims dating back before the Moghal conquest, though, legally speaking, their only title was the imperial sanad, had no doubt mach to do with the rapid growth of the power and pretensions of the whole class, of which we shall presently speak.

It may at first sight appear strange that the British revenue administration, after 1772 , soon came to distrust the zamindars; but in fact the evils of the system as a whole were more obvious than the merits and claims of a certain class. Probably all zamindars were found to oppress the people a good deal, and certainly they intercepted a large proportion of the state revenue. Attempts were therefore made to set them aside and to substitute contractors, bound by short leases-for five years, or.for one year-who would have no pretensions beyond the terms of their engagement. But the zamindars had by this time been too long and too firmly established to ensble such a plan to work, or to make their own wholesale supersession other (in many cases) than extremely anjust. Consequently Pitt's act of 1784 (24 Geo. III. cap. 25) clearly pointed to the restoration of the zamindars (under due restriction) and to the making of a settlement with them. Lord Cornwallig was sent out in 1786 to carry the act into effect, and the instructions 
of the directors of the East India Company hardly left him any option in the matter.

Any definitive arrangement of the land system must necessarily have in view three objects-(1) to determine the assessment of each 'estate,' and for what period it should hold good; (2) to give the persons responsible for the payment ${ }^{6}$ a secure position which could be legally described and enacted; (3) to determine what was to be done to protect the village cultivators over whom the zamindar (whether as the once hereditary local raler or as the officially appointed farmer) had grown up.

(1) As to the amount of the assessment, the only practicable plan (seeing that a land survey and valuation were deomed impossible or were never contemplated as possible) was to take an average of past collections, and so arrive at a ronnd sum which could be forthor adjusted with reference to the various specisl arrangements of the settlement-a matter of detail which it is not necessary here to consider. As to the period for which the sasessment was to be maintained there was a marked division of official opinion. Sir W. Hunter urges that Lord Cornwallis was not responsible for its being at once made perpetasl, becanse his instructions were to make it so. This can, however, hardly be conceded. The act of 1784 provided nothing which required, or even implied, that the assessment shonld be fired for ever. ${ }^{7}$ Reliance is, however, placed on the terms of the directors' despatch of 12 April 1786 (par. 52), which said, "The assessment now to be formed shall, as soon as it can have received our approval and satisfaction, be considered as the permenent and unaiterable revenue,' \&c. But this phrase should not be taken apart from the other instructions given; for these further distinctly declared that at present the settlement was to be made for ten years; and it was added that the directors felt ' that the frequency of change had created such distrust in the minds of the people as to render the ides of some definite term more pleasing to them than a dubious perpetuity.' There was no reason, then, why the ten jears should not have been allowed to ron out, so as to see how the new settlement worked; and it was in opposition to the best local advice that Lord Cornwallis urged the directors, when the gradus process of settling district by district was complete, at once to declare the assessment perpetual. The directors evidently had doubts also, and it was only after two years' deliberation that they (in the end of 1792) sanctioned the

- Or ' holding the settlement,' as the revenuo phrase in.

'In reading the doecomonts of this period it. shoold be borno in mind that the term 'permenent,' now used only to indioate that the seacosment is unalterable, wes then just 25 often exployed to indicate firity of syutem - with referenos to the former ahenging mothods of working. This weo of terms is well illnotrated by the montenen in the Bitth Roport (rol i. p. 14), where the writer apenks of "the introdaction of a permanout settlement, stterwurde made perpotral." 
governor-general's proposal, not without some apparent reluctance.

(2) As to the second of the objects above stated, Sir W. Hunter urges that the settlement orders consolidating the position of the zamindars were 'neither consciously nor unconsciously an imitation of the English system of landed property' (vol. i. p. 45). If this is said in refatation of such crade objections as those of Mr. Mill, that the settlement was the resalt of Lord Cornwallis's ' aristocratic prejudices,' it may at once be admitted. Bat Sir W. Hunter seems at any rate to imply that the confarment of a landlord title was solely or chiefly the result of inquiries and conclusions as to the Indian law and constitution. It is not easy to see how the historical and local information obtained in Bengal could have led to the landlord law of the Regulations of 1793 without the strong influence of English legal idess.

Allusion has already been made to the different origin which the 'samindars' really had. Sir W. Honter has, in his ususl felicitous manner, sketched for us the position held by one of the old aristocratic territorial zamindars, and has been perhaps too kindly silent as to the position of some of the other class whose origin was purely official, and who had built up estates-adding village to village and field to field, often by frand, riolence, and other questionable means.9 But while it is perfectly just to say of some of them that they had, on grounds of long possession and hereditary right, ' a good title to the zamindari estate' (p. 37), and that they were 'ancient hereditary lords of certsin tracts, a status which enabled them to levy grest incomes' from the land (p. 41), that admission does not suffice to determine the nature of the interest which time and circumstances bad established. The question for the Bengal anthorities was not 80 much whether there was a good title of some kind, but how they were to define the interest which it was desired to secure. And the mode in which they answered the question shows manifestly the influence of English ideas of landed property.

No doubt elaborate inquiries ware made, with the object of throwing light on the local history of the zamindar's position. But priving the objection that 'the lar and constitution of India' is a mere phrase, and that no such thing practically existed, at any rate in the eighteenth century, it must be admitted that neither the old text of the Hindu or Mahsmmaden law books, nor the local

- Bir J. Kego bes atated Lard Cornwallis's position in this mettla with moch tairnow (1draimictration of the EI. Company, 1853, p. 182).

- Compare, tor example, Dr. Buchenan (Brimilton's) secount of the Diaifjor distriet (printed in 1838), in which the anthor desoribes bow the great semindari of Dinijpur atuned its mushroom growth. The fint founders ware nobodies who grow riah and then sought for, and obtained, the titlo of raje, and nutimately mahsraje. The socount wes written within ten or tweive jears of the permenent settlement. 
custom (which mostly related to the village and its agricultural occupation) gave the slightest hint as to how the zamindar's gradually altered position should be classed or defined.

The original condition of right in land, broadly speaking, Fras this: The whole area of the cultirated districts (we may confine ourselves to the central popnious parts) was, as usual, divided into groups which we call 'villages.' These were of the type in which no co-sharing body or single family is found claiming the whole; but the holders of land are separate anits kept together by the anthority of the headman and other village officers and formed into a 'community' by the local ties which result from residence together, from common interests, and from having all the simple wants of life prorided for within the circle of the village, by a resident staff of artisans and menisls. ${ }^{10}$ In Bihar there is evidence of co-sharing families having obtained the chief pasition in the villages; but not in Bengal. Now under the Hinda, and equally under the (much later) Mnahammadan law, the village landholders-descendants, or at any rate direct representatives, of the first settlers, were certainly owners of the land in some sense, though oriental texts could not be expected to formulate the nature or the legal elements of ownership. A right in the soil was, however, acknowledged as resulting from the first occupation and laborious clearing of the land ; and that this was a substantial right is indicated by the many terts which refer to the maintenance of boundaries and fences, to repressing trespass, and to the succession to the land by inheritance as well as by gift and sale, the right of transfer being restricted only in much later times. Coincident with this direct soil right was, however, the right of the king to a share in the produce, and to the waste lands, and to certain transit and other dues and tolls leviable. When for any reason the rajja made a grant of a village, however exhanstive the formal terms of the document, all that was meant was that the grantee was to take all the royal rights, inclading the whole or a part (according to terms) of the revenue ahare, and the right to cultivate the waste. The rights of the original holders were not touched.

The more the old texts and the grants are examined, the more clearly it will appear that the 'law and constitation' contemplated two concurrent rights-(i.) a direct soil ownership in virtue of occupation and clearing; (ii.) an overlord right, which consisted in

\footnotetext{
10 Bech villege hed in those daye 20 indefinito sres of woste around it: thin wes

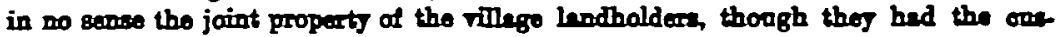
tomary wes of it for grasing and wood-outting. When oulttration was to be extended, permission, express or twefit, we required to coonpy the new fields. The wasto remeined the property of the atate : and this is orident trom the fuct that when a grante of the villege sppeared, he alrnge took the waste se lewtally his own under

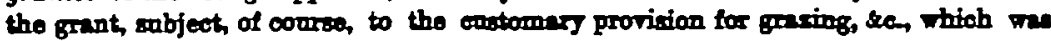
necoseang to the wellere of the origimal holders.
} 
the revenue share and the other rights incidentally above alluded to." The text-writers do not suppose that the first right is destroyed, or even diminished, by the existence of the second.

So long as the overlord right was exercised directly b5 the ruler himself, seated at his capital, in practice it was not found to interfere with the coltivator's right. But it contained in itself elements that might produce a change ; for the rajja's ahare could be increased ; ${ }^{12}$ and if it was not paid, coercive measures might be employed. When, therefore, in later times not only did a conquering dynasty raise the revenue share, bat grantees, or pushing families, or adventurers (in the local raids of ansettled times) got hold of villages, they exercised the overlordship at close quarters, so to spesk, in a much more direct and self-assertive fashion. And especially when the state overlordship and revenue rights were farmed out, the farmers (of whatever class or origin) were brought into a close managing connerion, sach as the dignified ruler at his capital, with his well-controlled officials, would never have thought of. Still, in theory, it is only the state rights that are the subject of the grant or farm.

But the more the local revenue becsme (virtually) the subject of a bargain with middlemen, the more the latter regarded it as a mstter of course that they ahould make as much profit as they could; and accordingly they (without check from the now powerlese officials) trested the raiyats as lisble to anything they thonght proper to impose. ${ }^{13}$ They would eject insolvent cultivators, would bay up some lands under pressure, and, by standing security themselves for the payment due from others, would soon have opportunity to foreclose on the owner. Apart, however, from his private (family) lands and actual purchases, \&c., the zamindar was never, on any possible theory, the actual owner of all the village lands; the hereditary räjā accepting a sanad from the Mohammadan ruler, was not, and a fortion the official farmer was not. But the fact remsins that when once the overlordship is transferred to the hands of some person, other than the territorial ruler for the

u Colonel Tod quotes s marim of the Rejputine illege lendholders, which exprocies correctly the feots in all tho ancient Binda bingdome-

'Bhogrt dheni Bajha

Bhamri dhani mijho'-

in 'tho king's wealth ' (or tight) ' is his revenue share; the coil is my wealth' (or right).

- The shere wes ono-rixth; but oven in the Inditutes of Manew wo find it stated that in timee of emargenoy the rxjn might raine it to one-fourth. There is nothing aboot ojection for non-pejment (ead in prection soch thing was ontorown), but the riji is dirooted to fine a ooltivator who nogloots to till his fleld.

- Tho ald aristocratio ceminder we not much better in this rospot then the speonlelor. The former, under presiuro trom the imperiel treasur, forgot too atten the nobleses oblige that woold have cetnatad bim in tho dejs of independence; and, beaider, bo laft the direot manegement to a boat of greedy modertinge. 
time being, it always tends to become a virtual but undefined proprietorship, and that in great measure by a series of steps the reverse of equitable. The difficulty is to attempt, at a later time, to question acts which, in some cases, have the prescription of several generations.

While grantees and farmers were gradually making good their pretensions, the old state right itself underwent a change. No trace of an assertion that the ruler, as such, is owner of all land can be found in the genuine Hindu or Muhammedan law." But later princes-and especially the viceroys who assumed independence-all set up the claim, as conquerors, to be the sole owners of land. By the close of the eighteenth century this was certainly established de facto. Iord Cornwallis was thus confronted with a double complication. The state right to which his government succeded, was de facto though not de jure: the zamindar's claim was not formulated, bat it was long existent in practice. Both the one and the other had very little to do with the "law and constitution;' not even with 'custom,' unless the results of anchecked aggression daring a century can be called 'costom.'

It was, then, as a matter of deliberste policy that the governorgenersl renounced the state right to the land and conferred it, in a new form, on the zamindars. ${ }^{1 s}$ The first part of this decision calls for no remark in this place; the second was largely prompted by the necessity for cutting the knot that conld not (80 it was felt) be untied. The terms in which this right was actually conferred on the zamindars by law are really more important than the expressions made use of in the governor-general's preliminary minutes. Bat it is impossible to read either minates or regalations without perceiving that the ides of the English landlord of the eighteenth century (of course assoming a good landlord as the type) was present to the minds of the writers ; indeed what other ides of legal property in land could they have had but that of a landlord, the owner of the estate, with all sabordinste holders his tanants - to be cherished and protected, no doubt, but still 'tenants,' holding. by agreement with him? And so we are not surprised to find in sect. 52 of Regalation VIII. of 1793 (this with Reg. I. constitutes the charter of the settlement) the provision 'that' (saving certain privileged holders whose title was obrious) 'the semindar or other actual proprietor

is The colobmeted modern digest of Jaganathe (written in Bix W. Janes's time and tranaleted by Colobrooko), howrvor valusblo in many reopeote, shows the mont pitieblo contarion on this sabject, in the hopeleses endesrour to reconoile the alder lew with the then establiehed doetrino that 'conquerors ' hed a 'proteotive properts' (whetover that meg be) 'in the soil of their territory.'

w In the prenmble to the second regulation of 1798 it is expresaly atuted that of tro mearures taken bJ government to restore eqricultural prosperity, one whes that ' the property in the soil has been declared to be rested in the landhalders (meaning the samindars) ; ' and this, it is added, ' hed never befare been formelly deetared' 
is to let the remsining lands of his zamindary, or estate, under the prescribed conditions, in whatever manner he may think proper.' The 'conditions' were that a written document was to be given, specifying one definite sum of 'rent,' and that no 'extras ' were to be exscted. Moreover it was speedily enscted that the landlord was not to give his pottah for more than ten years, lest he should injure himself and his means of peying the state revenue. All this implies that the raijat was a 'tenant' onder contract; and it soon became accepted that rents conld be raised.

(8) But this question of 'reising the raiystg' rents' invites is brief separate notice in connexion with the third object of the settlement above noted (p. 281). It never occurred to any one to restore the resident or permanent village caltivator to the position of owner of his holding; that would have been inconsistent with the declaration regarding the zamindar's rights. Still it would not much matter to the (resident) raiyat what he was called, provided it had been recognised that his tenancy was by castom, not by contract, and that his rent payment was, therefore, to be certain, and to be raised only at such interrals and on such terms as it could have been, under state anthority, in olden time. It is andeniable that the official minutes contain directly conflicting pronouncements on this subject. On the one hand it was not forgotten that what now became the ' rent ' payable to the ' landlord or other actual proprietor' (of the regulations) was merely the revenue pryment that wonld, if there was no farmer, have been paid direct to the state collector. And Lord Cornwallis sometimes wrote ss if these payments were fixed absolutely, at rates supposed to be ascertainable from local records. ${ }^{16}$ It would have been possible, no doubt, to include in the proclamation to samindsrs a reminder that they had originally no right to raise the raiyats' psyments unless the state itself raised them ; and it would then have been logical enough to declare that as the state had limited for ever its demand on the zamindars, and had presented them freely with the nnoccupied waste adjoining their estates, and had given other advantages, they must forego any increase on all such raiyats as were not directly located by themselves on newly cultivated land.17

But, on the other hand, there was no obligation to make such a condition. There is no doubt that, if there had been no tarmers or other grantees at all, the revenue demand from the original soil owners conld have been revised from time to time. A good government would have made such a revision only at long intervals, and on such principles as are allowed to operate at the present day

10 This ides of the intended frity of 'ronts' is the basis of the sroment in the 2nowymous work anlled The Zamindari Settlement of Bengal (Caloutten 1879, 2 vole), quoted by Bir W. Hanter.

17 Bents on this would, of coarse, be purely msttar of contract vith the orner. 
in other provinces. ${ }^{18}$ The grant of a certain legal status and other privileges to one party did not necessitate any grant or free gift to the other, unless, indeed, the grant to the first caused some direct injury to the second; and that it was neither intended nor supposed to do.

The question of raising rents was discussed in 1789 , as appears from Harington's 'Analysis." Is It was at this time that John Shore put forward his 'Plan for the Ease and Security of the Raiyats.' He had already recognised (in his minute of $18 \mathrm{June}$ 1789) that the position of the raiyat was anomalous, and he contemplated its gradual adaptation to the 'simple relation of landlord and tenant.' He proposed that every landlord should be compelled to agree to make a: systematic inquiry, over the whole of his estate, for the purpose of fixing (and entering in a written note) the rent of every resident village caltivator. ${ }^{20}$ This was to be done within a given number of years; the number Shore left blank in his minate, as a detail for sabsequent determination. It was then believed that, what with the information from the local lists of rates (to be mentioned presently) and the necessity that the parties would feel themselves under to find some modus vivendi, terms would be settied.

Lord Cornwallis would not consent to defer the ratification of the settlement till such an inquiry was complete; nor did he do more than pass a regulation making the issue of pothahs compulsory on the landlords. There was, moreover, no means of enforcing the law; and it was soon found that 'tenants' objected to take the pottahs; some, because they feared that, unlettered as they were, terms which they could not read or understand might be imposed thereby; others, because they felt that accepting such a document meant admitting that they held of the zamindar and not by an independent, customary, or legal right. It is true that the pottah was not exactly what we should call a lease, but it certainly had this effect. The pottah regulation, in fact, failed altogether.".

1" It should be borne in mind that in theory, the lend revende represents a certain proportion of the income or benefit derivable from cultivated land. Bren in modern temporarily settled provinces (ice where the ossessment is lisble to periodical ro vision) in increase is taken, not to raise the proportion spoken of, but because, under existing conditions as to value of money, increased provluce, or increased value of lanc, and bighor market prices of grain, the gum paid unler the iagt assessment no longer represents the proper proportion.

10 Vol. iii. p. $161 \mathrm{ff}$.

- Other, it may be presamod, than those directly located by himself on new lands, and who were indisputably contract tenente.

II Its failure was owing largely to its own terms : it might naturally be thought that if the raijat would not accept, or could not get, a thir potta $h$, the remedy would bare been to allow (as the Medres semindari law ellows) either party to epply to the collector to 6x a proper rate. The only protision, howerer, was that the lendlord abould post op 2 list of the rates he demanded; and if the raiyat did not contest them (by the to him impossible process of a cosuly sait at distant head-quarters) he conld be made to pay at guch rates. 
Even if these difficulties could have been evaded, and present rates fairly ascertained in most cases, it was still necessary to decide whether the raiyats' rents were liable to any future increase or not. Obviously, if the intention was positirely entertained to make the rates fixed, this was one of the very tirst terms to be set forth with all plainness in the regulations. As it was-and here we must perceive the influence of the English ides of landlord und tensntnot only was it directly enacted that (sabject to the conditions indicated) the landlord 'was to let his lands' in any manner he chose, but it was specifically said that such raiyats as could prove a special grant or a prescriptive right were entitled to fixed rents. The inference, therefore, was inevitable (at least in English courts) that othercise rents conld be raised."

The matter was further settled by the influence of two messures, which, though enscted with the best intentions, were productive of unforeseen results. One was the 'sale law,' which provided the remedy for revenue default. Within a short time after the settlement, the earlier practices of imprisoning defaulting landlords and distraining their personal property were abolished, as trenching on the dignity and freedom of the position. But it had been roled from the first that the fired revenue (which would gradually become lighter and lighter as land and its produce rose in value and as new land was profitsbly cultivated) must be punctually paid ; and therefore the estate, or part of it, woold be sold at once if default was allowed to occur. Now, as a careless or dishonest manager might burden his estate recklessly, and so destroy its sale value before defaulting, it was necessarily provided that contracts and charges imposed by the defaulter were, with certain exceptions, void or voidable as regards the purchaser. When a sale occurred-and, as Sir W. Hunter has explained, this at first very frequently happened-most rents had to be fixed afresh, practically at the pleasure of the new owner. The second measure was passed in 1799. The landlords complained that while the state demanded its revenue with strict punctuality, they had no correspondingly speedy means of recovering the rents, on which their ability to pay depended. A power of summary distraint was accordingly given, and terms of the regulation (VII. of 1799) were found so to operate

- In 1808 Colonel Munro, whose enthority on revenuematters will not be questioned, wrote: 'I make this conclusion upon the supposition that they '(the semindan) ' are to be at liberty to raise their rents, like lendowners in other countries : otherwise if they an restrioted trom rasing the assessument . . . and are at the semo time lieble for all lowes, thoy here not the trw menagement of their extates and hardly descorve the neme of owners' The whole cubject (inoludiog the racious minutes written and the provisions of the reguletions) is fairty summod ap in DT. Fiald's Iandrolding in various Countries (Celentten 1885, 2nd ed), pp. 536 il.

20 The only remedy we the slow and contly procese of a regalar cinil anit at the dirtriet head-quartars. See, for instance, the letters Nos 3848-9 (Jan. 1794), in rol ii. 
that the landlord could realise very much what he chose to declare to be the correct rent.

These provisions, worked as they were under the influence of the idea that a rise of rents was only a natural feature of landed property, would nevertheless have been much shorn of their ill effect if there had been any standard by which to ascertain the proper rent rates, but this was almost wholly wanting. The real fact of the matter is, that no plan like Shore's, nor indeed any other plan for the comprehensive adjustment of the surviving privileges of the (now subordinate) landholders, nor any rule of tair rent assessment, conld have been effective without a survey of holdings and a new record of rights; and both were impossible, or beyond the realm of practical contemplation, at the time." It is not really a tenable view, that 'records of right' or satisfactory lists of customary rates prevalent in parganas existed-certainly not of such a kind as would have ensbled protection to be given by written rules or regulations on the sole brsis of their contents. Still less is it possible to conclude that the non-retention (as government servants) of the accountants of villages, and the abolition of the kaningas of fiscal subdivisions, were the causes of the failure of the settlement to provide due protection for the raigats.

The lists of village and pargana revenue rates (now become the middlemen's rents) were never records of right or title, as modern settlement records are; and the rates themselves had become so various and so unequal, that no just conclusion conld be drawn from them in the case of a dispate. ${ }^{25}$ And the settlement did not abolish the villsage control or its accounts. On the contrary Regulation VIII. expressly provided that if in any village a patwodi (accountant) did not exist, one was to be forthwith appointed. The government persisted in the effort to restore these officers for some years. 25

But the whole ideal of the new position conceded to the landlords was, to leave them in as much independence as possible, and to refuse to pry into the internal affairs of their estates. As

24 It was not till 1822 that Holt Mactrenzio scoceeded, in the N.W. Provinoes, in enforcing (eqainst considerable opposition) the necessity of a survey and record of rights. Even then tor twenty years the antborities hed gone on (in those provincas) trying to do writhout eithar. But by 1822 the necessary establishments were much more easily attainable.

27 How mach this was the case may be seen trom the proofs collected by Dr. Field (Landholding, sen Pp. 606-7). Mr. Colebrooke's able minate of 1812 pat in the clesrest light how worthless these records were, when they oxisted at all. It is troe that this minute was written some twenty years atter the settlement; but long before that the semindari management (hardly controiled at all by the state) hed upset all regolarity in the rates or in the liots of them.

- We find records in the rolmos up to 1801, gtill asting if the orders had been carried into effect. Bee, for instance, No. 5891 (Cireutar), in Jano 1796; No. 6601, Jaly 1797 ; No. 8780, Jenuary 1800. 
the revenue payable was now fixed for ever, and (under such circumstances) was to be paid without regard to temporary profits and losses, the control of the kaningo of each local subdivision ceased to be of any use. ${ }^{27}$ The only thing sach an officer could do would be to watch against oppressive acts of the landlord, and maintain the rights of his subordinate landholders; this was an imposeible position, eren if he had the moral courage to attempt it. And very much the same was true of the village accountants. How could they be maintained as servants of government-that is, in a position (as the lawyers s8y) 'sdverse' to the landlord? Of course their accounts were kept, and had been increasingiy so kept, long before the settlement, not 80 as to be a check upon the landlords, or to maintain the rates reslly due from the raiyats according to the last anthorised adjustment of them, but 80 as to facilitate the colleotions of the landlords, at rates which the government had (in fact) long allowed them to dictate. Both kaningos and patwaris, therefore, became useless as checks, and the government found it a aseless expense to pry them.

The fact is that the old aystem of graduated local control was effective only on the supposition that direct dealings with the original village proprietors were continued. At the present day the system only works to advantage in provinces where government deals directly with the villoges, whether with the individual holders, as in the great western and sonthern provinces, or with cosharing village proprietary bodies regarded as jointly responsible unita, as in North-West India The ultimate abolition of government-paid local agents was the necessary outcome of the system of acknowledging great local landlords. ${ }^{28}$

It is not too much to say that the root of all the early tonant difficulties in Bengal was, just 89 in Ireland, the inability of the anthorities to contemplate a relation which they might call a 'tensncy' if they pleased, but which founded on status, not on contract. It is worthy of remark that at the time of the permanent settlement, the modern capitalist theory of rent was not invented; nor did it appear till some twenty-five years latar. Still it was thought that rent was the result of 8 matual agreement based on the intritive feeling of either party as to what one was able to ask and the other would find it possible to pay. And under

- As early as February 1788 (rol. i Na. 1169) report was made that the bäningos ware of no ves. In July 1798 (rol L No. 2916, 2928, 2970, and 3014) the ordars wore given for sbolition. Attempts at restontion vere mado in 1816-9.

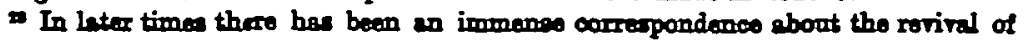

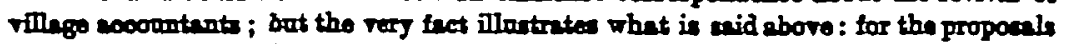
onf arow when the old asmindaris hed boen lergely broken up (seo Bir W. Hurtor's rumarts, i 110-4) and a greatly increseed nomber of moch amilles entates hed to

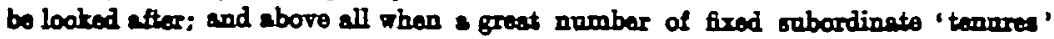
and toment rights vere actonotriedged by lew. 
the influence of such an idea, as the necessary concomitant of a landlord and tenant tenure, the framers of the regulations omitted to declare that permanent (or resident) raiyats' rents could not be raised, and left the perfectly natural inference 20 that they could. The worst feature in the ancertainty thas created was not 80 mach that rack-renting became very prevalent, for that may be doubted; ${ }^{30}$ but that year by year the means of distinguishing between tenants who were really the original landholders or their direct representatives, and those who ored their position to a subsequent personal contract with the landlord, became more and more difficult to find. Ignorant peasants do not know how to preserve proof of material facts; and in the end some arbitrary rale has to be resorted to, when the legislature desires to classify tenants into those who have rights of status and those who have not.

But the after history of the tenant question belongs to a period long subsequent to the records in Sir W. Hunter's four volumes. A few words may, however, be added to complete the story, at least as far as the first tenant law. An official inquiry was instituted in 1811, which produced (among others) a minute by Mr. H. Colobrooke, that attracted great attention and resulted in the passing of Regalation V. of 1812. This law endesvoured to limit the alteration of rents on the occurrence of a sale, and to find an equitable rule for fixing rents by comparison with those paid on similar adjacent lands. The low was ungestionably designed to be in redress of tenants' grievances; but unfortunstely, being defective in itself, and also nullified by other legislation, it only added to the troubles it was mesnit to relieve. Nert, Lord Moirs wrote a notable minate in 1815, which indicates the ahange that had come over official opinion; but matters were not then ripe for a comprehensive tensnt law. It needed the experience of another great settlement-thst of North-West India-before a practical mode of dealing with tensnt rights suggested itself. At last, in 1859, the first ides of a tenant lsw found expression. In the meantime some of the difficulties were obvisted, or at least lessened, by the increased number of the courts, and their being more accessible and more speedy in deciding; the 88le lBW Fas improved, especially as to the extension of the list of existing leases and tenures which were not voidable on a sale; there was also a gradusl improvement in the mode of registering

- Beo Colonel Munro's romactes, quoted above, p. 288 , n. 22.

- In opite of all the occusionel ar trequent hershness of lendlords, cortom, if only rocent oustam, and the thet that neighbouring lands of the anmo quality must nato-

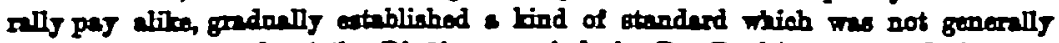
inosed. In his stady of the Dinxipur raminderie, Dr. Buchinan noticed thet the

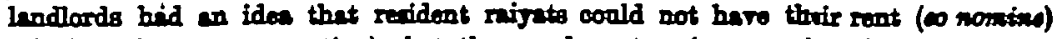
raised (writhout state wanction); but they made ort an incroves in other wase. The prohibition againgt ' eutras' never was roally affootive a long as tho toments woold mhmit to the demand. 
subordinste interests and so protecting them. These interests are now numerous and afford a rather curious stady. One large class, the modern patnit tenure, has been msde the subject of some very interesting remarks by $\mathrm{Sir} \mathrm{W}$. Hunter. These tenures cannot, however, here be further noticed. The latest Bengal law (revigion of 1885) has found it desirable to ase the word 'tenure ' in a special sense, to indicate these intermediste interests, which lie halfway, as it were, between soil ownership and contract tenancy.

One possibility of finsl solution for tensnt troubles still remains unapplied. Alone among the provinces of India, Bengal has no cadastral survey, and consequently no agricaltural statistics. Topographical maps, and to some extent surveys of the outer boundaries of estates and even villages, exist, but that is all. This is a subject which would require a separate article to explain. If Bengal has prospered onder the permanent settlement, it is not because of the principles of the settlement or its law. It is because a firm, and on the whole good, administration, profonnd peace, a free and ever expanding market, and a naturally fertile soil, have produced their own amoliorating results. Edacation, too, is slowly filtering down to the tensnt class, and has done something to make them more self-raliant and able to maintain their rights.

B. H. BLDER-POWRTr. 